\title{
Spatial extension of nucleating air masses in the Carpathian Basin
}

\author{
Z. Németh and I. Salma \\ Institute of Chemistry, Eötvös University, Budapest, Hungary \\ Correspondence to: I. Salma (salma@ chem.elte.hu) \\ Received: 19 February 2014 - Published in Atmos. Chem. Phys. Discuss.: 4 April 2014 \\ Revised: 15 July 2014 - Accepted: 21 July 2014 - Published: 27 August 2014
}

\begin{abstract}
Particle number size distributions were measured by differential mobility particle sizer in the diameter range of 6-1000 $\mathrm{nm}$ in the near-city background and city centre of $\mathrm{Bu}$ dapest continuously for two years. The city is situated in the middle part of the Carpathian Basin, which is a topographically discrete unit in the southeastern part of central Europe. Yearly mean nucleation frequencies and uncertainties for the near-city background and city centre were $(28+6 /-4) \%$ and $(27+9 /-4) \%$, respectively. The total numbers of days with continuous and uninterrupted growth process were 43 and 31, respectively. These events and their properties were utilised to investigate the spatial scale of the nucleation in the basin, and whether there are any specific trajectories for the nucleating air masses. Local wind speed and direction data indicated that there seem to be differences between the nucleation and growth intervals and non-nucleation days. For further analysis, backward trajectories were generated by a simple air parcel trajectory model. Start and end time parameters of the nucleation and an end time parameter of the particle growth were derived by a standardised procedure based on examining the channel contents of the contour plots. These parameters were used to specify a segment on each backward trajectory that is associated with the nucleating air mass. The results indicated that regional nucleation happened in the continental boundary layer mostly in the Carpathian Basin but that the most distant trajectories originated outside of the basin. The nucleating air masses were predominantly associated with NW and SE geographical sectors, and some of them were also related to larger forested territories. The results also emphasised indirectly that the regional new particle formation and growth phenomena observable at the fixed location often expand to the bulk of the Carpathian Basin.
\end{abstract}

\section{Introduction}

It is increasingly recognised that ultrafine (UF) aerosol particles influence our life and environment in many important ways. One of their sources is atmospheric nucleation. Field measurements suggest that nucleation is a worldwide phenomenon (Kulmala et al., 2004), and that nucleation is a substantial source of these particles (Spracklen et al., 2010; Yu et al., 2010). In addition, the freshly nucleated particles are able to grow into size ranges where they can act as cloud condensation nuclei (CCN) (Laaksonen et al., 1998; Andreae and Rosenfeld, 2008; Wiedensohler et al., 2009), which are associated with important indirect radiative effects in the climate system (Wang and Penner, 2009; Kerminen et al., 2012; Makkonen et al., 2012). Global model investigations indicate that at least $50 \%$ of $\mathrm{CCN}$ is formed by condensational growth of nucleated particles (Merikanto et al., 2009). Even in urban environments, contribution of nucleation to UF particle concentrations with respect to all sources is between 23 and $43 \%$ in the spring and summer seasons (Salma et al., 2014). This emphasises the possibility of significant health consequences of nucleated particles in cities - in addition to their climate relevance. Ultrafine aerosol represents an excess health risk relative to coarse or fine particles of similar chemical composition (Oberdörster et al., 2005) due to the large number of insoluble particles that can be deposited in the respiratory system, their large surface area, and very small size (Kreyling et al., 2006, HEI Review Panel, 2013).

New particle formation and particle growth events have been identified on the regional scale in a variety of geographic locations around the world (Kulmala et al., 2004; Kulmala and Kerminen, 2008). In clean environments, horizontal extension of nucleating air masses can reach up to hundreds of kilometres (Kulmala et al., 1998, 2001; Vana et al., 2004; Komppula et al., 2006; Väänänen et al., 2013). 
As far as the vertical occurrence is concerned, nucleation was observed at altitudes ranging from surface locations (Kulmala et al., 2004) up to the free and upper troposphere (Clarke et al., 1998, 1999; Minikin et al., 2003). In addition, several long-term observations indicated that there can be some larger regions associated with nucleating air masses (Coe et al., 2000; Fiedler et al., 2005; Hussein et al., 2009; Komppula et al., 2006; Young et al., 2007). For instance, Kristensson et al. (2008) suggested that there is a relationship between the new particle formation and ship emissions; Hirsikko et al. (2013) reported a source area which was near their measurement site in a savannah; and nucleation events observed at the SMEAR-2 (Station for Measuring Forest Ecosystem-Atmosphere Relations) station in Hyytiälä (Finland) were linked to air masses which frequently originated from the Baltic Sea (Kristensson et al., 2014).

The Carpathian Basin is a topographically discrete unit situated in the southeastern part of central Europe. Its central part (mainly lowlands) is surrounded by the Alps from the west, by the Carpathian Mountains from the north and east, and by the Dinaric Alps and Balkan Mountains from the south, which represent important barriers to the movements of air masses. Linear dimensions of the basin in the $\mathrm{N}-$ S and W-E directions are approximately 400 and $700 \mathrm{~km}$, respectively. These extensions are comparable to distances into which nucleating air masses can ordinarily reach. There are some extensive wooded areas within the Carpathian Basin (in the surrounding mountains and Transylvania) with expectedly cleaner regional air, which can be, however, loaded by biogenic precursor gases. There is a two-year-long new particle formation and growth event data set available for Budapest, which is situated in the middle part of the basin. Concentration and other physical properties of the nucleated and UF particles in Budapest have been characterised previously (Salma et al., 2011, 2014). It is just noted here that yearly median particle number concentrations in the nearcity background and city centre of Budapest were $3.4 \times 10^{3}$ and $11.8 \times 10^{3} \mathrm{~cm}^{-3}$, respectively. The major objectives of the present paper are to improve the available method for assessing the trajectory segments related to nucleating air masses, to investigate whether there are preferred directions for them within the Carpathian Basin, and to discuss the spatial extension of the area which can have influence on the ground-based station located in the middle of the basin.

\section{Methods}

\subsection{Experimental}

Particle number size distributions were continuously measured at two sites in Budapest, Hungary, for one year each. Between 3 November 2008 and 2 November 2009, the measurements were carried out in the city centre at an open area near the Danube (Lágymányos Campus of the Eötvös University; $47.474^{\circ} \mathrm{N}, 19.062^{\circ} \mathrm{E} ; 114 \mathrm{~m}$ above mean sea level) (Salma et al., 2011). From 19 January 2012 to 18 January 2013, the measurements were realised in a near-city background at the NW border of the city in a wooded area (Konkoly Observatory of the Hungarian Academy of Sciences; $47.500^{\circ} \mathrm{N}, 18.96^{\circ} \mathrm{E} ; 478 \mathrm{~m}$ above mean sea level). The measuring system consisted of an identical flow-switching type differential mobility particle sizer (DMPS) and a meteorological station. The main components of the DMPS system are a ${ }^{241} \mathrm{Am}$ neutraliser, Nafion semipermeable membrane dryer, $28 \mathrm{~cm}$ long Hauke-type differential mobility analyser (DMA), and a butanol-based condensation particle counter (CPC, model 3775, TSI, USA) (Salma et al., 2011). Particles with an electrical mobility diameter from 6 to $1000 \mathrm{~nm}$ are recorded in their dry state in 30 channels. The DMPS measurements were performed according to the recommendations of the international technical standards (Wiedensohler et al., 2012). Basic meteorological data, including wind speed (WS) and wind direction (WD), were obtained from the Urban Climatological Station of the Hungarian Meteorological Service operated within the university campus above the rooftop level, or from an on-site meteorological station at a height of $2 \mathrm{~m}$ from the ground at the near-city background. Time resolution of all measurements was $10 \mathrm{~min}$.

\subsection{Data treatment and modelling}

The DMPS data were inverted and were represented in contour plots showing the time evolution of both the normalised particle number concentration and particle diameter on a daily basis. The measurement days were then sorted into evident nucleation events, unambiguous non-nucleation days, and undefined and unclassified days (Dal Maso et al., 2005). In the present study, nucleation events with continuous and uninterrupted growth process, namely class $1 \mathrm{~A}$, were considered. Wind speed and wind direction data were utilised to create wind roses that are based on the modern Beaufort scale separately for non-nucleation days, and nucleation and growth intervals for class $1 \mathrm{~A}$ events. For the former case, wind data for the whole day were included. For the event intervals, a narrower time interval that started $1 \mathrm{~h}$ before the onset of the nucleation and ended $6 \mathrm{~h}$ after the onset of the nucleation (thus from $t_{1}-1$ to $t_{1}+6 \mathrm{~h}$; see later) was taken into consideration.

Retrospective movement of the nucleating air masses was assessed by backward trajectories generated by the HYSPLIT (Hybrid Single Particle Lagrangian Integrated Trajectory Model) code version 4.9 (Draxler and Rolph, 2013). The principle of the process has been described previously as NanoMap for remote regions (Kristensson et al., 2014). Three time parameters are required for each nucleation event (banana curve) in order to calculate the set of trajectories and to locate the most distant segment on each trajectory. The time parameters are the following: the end time parameter 


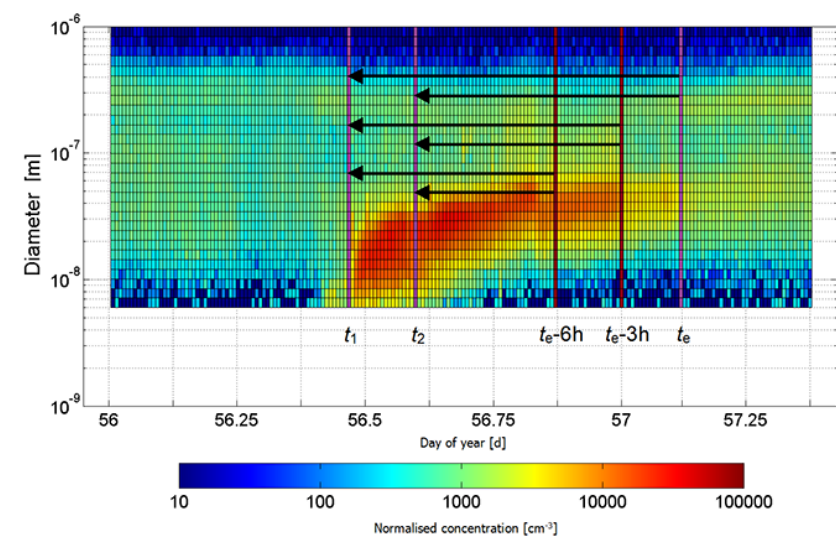

Figure 1. Determination of the start $\left(t_{1}\right)$ and end $\left(t_{2}\right)$ time parameters of the nucleation, and the end of the particle growth $\left(t_{\mathrm{e}}\right)$. The three arrow pairs correspond to three backward trajectories arriving to the measurement site at times of $t_{\mathrm{e}}, t_{\mathrm{e}}-3 \mathrm{~h}$, and $t_{\mathrm{e}}-6 \mathrm{~h}$, and determine three limiting segmental pairs corresponding to $t_{\mathrm{e}}-t_{1}$ and $t_{\mathrm{e}}-t_{2}, t_{\mathrm{e}}-3 \mathrm{~h}-t_{1}$ and $t_{\mathrm{e}}-3 \mathrm{~h}-t_{2}$, and $t_{\mathrm{e}}-6 \mathrm{~h}-t_{1}$ and $t_{\mathrm{e}}-6 \mathrm{~h}-t_{2}$ on the air mass trajectories.

of the particle growth process $\left(t_{\mathrm{e}}\right)$, start time parameter $\left(t_{1}\right)$, and end time parameter $\left(t_{2}\right)$ of the nucleation process. Further steps of the treatment are illustrated on a contour plot in Fig. 1. The particles that arrived to the measurement site at time $t_{\mathrm{e}}$ had been generated previously at a site expressed by the end segment of the corresponding backward trajectory. The limiting points of the segment are determined by the time points of $t_{\mathrm{e}}-t_{1}$ and $t_{\mathrm{e}}-t_{2}$. Similarly, the particles that arrived to the measurement site at time $t_{\mathrm{e}}-1 \mathrm{~h}$ had been generated at a location expressed by a trajectory segment that corresponds to the arrival time $t_{\mathrm{e}}-1 \mathrm{~h}$ time and limiting parameters of $t_{\mathrm{e}}-t_{1}-1 \mathrm{~h}$ and $t_{\mathrm{e}}-t_{2}-1 \mathrm{~h}$. The trajectories were calculated and their segments were determined consecutively for arrival times that were repeatedly decreased by $1 \mathrm{~h}$, thus for $t_{\mathrm{e}}, t_{\mathrm{e}}-1 \mathrm{~h}, t_{\mathrm{e}}-2 \mathrm{~h}, \ldots$ until the difference between the $t_{\mathrm{e}}$ and $t_{2}$ became $1 \mathrm{~h}$. The set of the segments marks the related nucleating air mass with a time resolution of $1 \mathrm{~h}$. The end points of the segments for all consecutive trajectories were finally connected, and the resultant plane figure represents the physical area (arrival field) of a particular nucleating air mass.

In cities, the atmospheric environment usually has more complex or dynamic character than in remote regions. Determination of the time parameters was, therefore, more rigorous in our study. The end time parameter $\left(t_{\mathrm{e}}\right)$ of the growth was set at the point when (1) the particle growth was evidently finished in the contour plot, (2) the nucleation mode increasing in the diameter joined the Aitken mode, or (3) substantial direct emissions occurred locally (for more than $1 \mathrm{~h}$ ). Determination of the $t_{1}$ and $t_{2}$ time parameters was based on the content of the first channel. A relative method was developed to consider the fact that the particle number concentration can vary substantially among dif- ferent (urban) environments (Salma et al., 2014). First, the maximum of the normalised concentration in the first channel $\left(c_{\max }\right)$ was localised. For the city centre, the $t_{1}$ and $t_{2}$ time parameters were set before and after $c_{\max }$, respectively, at a concentration level of $c_{\max } / 4$ if $c_{\max }>40 \times 10^{3} \mathrm{~cm}^{-3}$, they were set at $c_{\max } / 3$ level if $c_{\max }$ was between $30 \times 10^{3}$ and $40 \times 10^{3} \mathrm{~cm}^{-3}$, and they were assigned to $c_{\max } / 2$ if $c_{\max }<30 \times 10^{3} \mathrm{~cm}^{-3}$. For the near-city background, these cut-off concentrations differed due to lower concentration levels and larger relative differences among the channel contents. If $c_{\max }>30 \times 10^{3} \mathrm{~cm}^{-3}$, then the time parameters were set at $c_{\max } / 5$; if $c_{\max }$ was between $15 \times 10^{3}$ and $30 \times 10^{3} \mathrm{~cm}^{-3}$, then they were assigned to $c_{\max } / 4$; and if $c_{\max }<15 \times 10^{3} \mathrm{~cm}^{-3}$, then they were set at $c_{\max } / 3$. The proposed schema represents a simple but effective method that handles fluctuating data reasonably well. Finally, the time parameters were shifted to a smaller value by a time interval that corresponds to the particle growth from $2 \mathrm{~nm}$ to the lower diameter detection limit of the DMPS (here $6 \mathrm{~nm}$ ) utilising the actual growth rate value. It was assumed implicitly that the nucleation takes places around $2 \mathrm{~nm}$, which is in line with recent direct observations of atmospheric molecular clusters (Kulmala et al., 2013).

For the actual HYSPLIT modelling, embedded meteorological data from the GDAS database were utilised, and trajectories arriving to the receptor sites at a height of 200, 500 , and $2300 \mathrm{~m}$ above ground level were calculated. The first height level has the main importance since the measurements were performed near the ground surface, and the other two heights were selected for checking and comparative purposes.

\section{Results}

\subsection{Nucleation frequencies}

Total numbers of evident nucleation days, of obvious nonevent days, and of undefined days relative to the number of all relevant days in each month for the city centre and nearcity background are shown in Fig. $2 a$ and $b$, respectively. The number of undefined days was regarded as the largest reasonably possible overestimation (if all events were misclassified as undefined day), while negative misclassification of one event day as a non-event day in a month was considered as the maximum sensible extent of underestimation. In this way, yearly mean nucleation frequencies and uncertainties for the city centre and near-city background were $(27+9 /-4) \%$ and $(28+6 /-4) \%$, respectively. The two frequencies are within the uncertainty limits, and are very close to each other. The values are larger than for ordinary background or remote sites (cf. Kulmala et al., 2004; Manninen et al., 2010; Kerminen et al., 2012), and somewhat larger than but comparable to most urban environments (e.g. Qian et al., 2007; Borsós et al., 2012; Dall'Osto et al., 2013). The nucleation frequency 

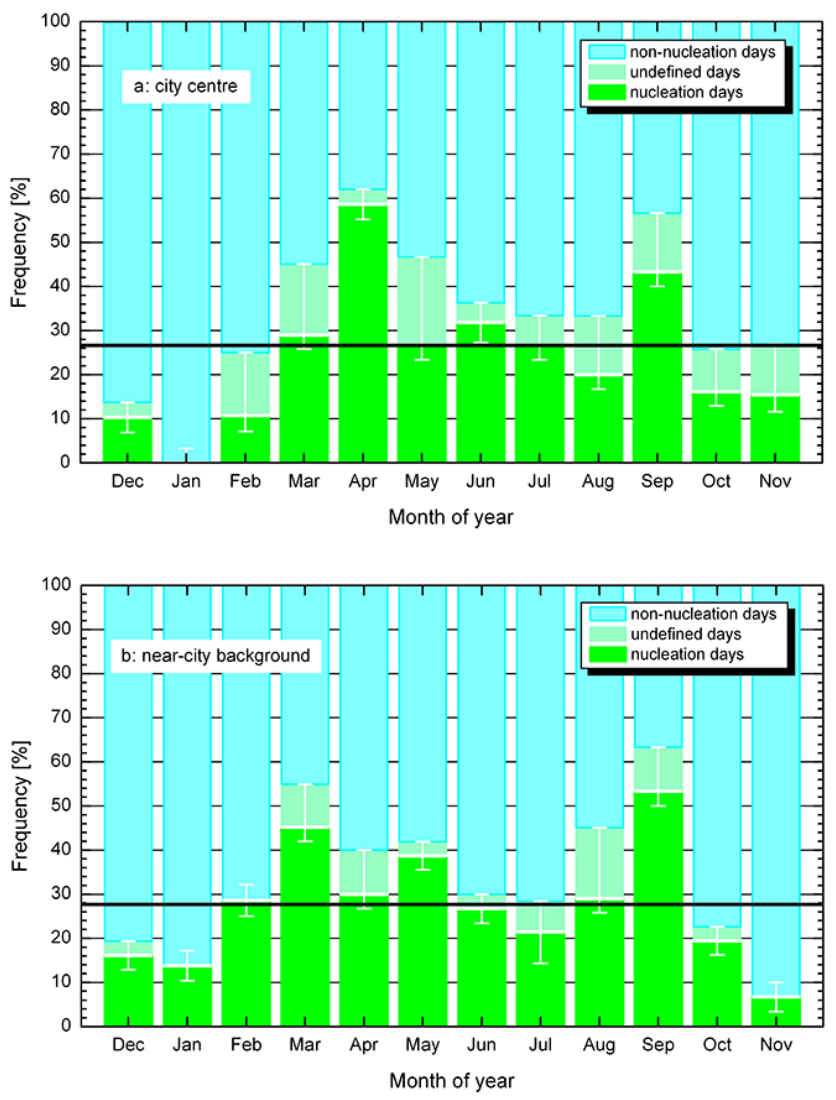

Figure 2. Monthly mean frequencies for days with new particle formation, undefined days, and non-event days in the city centre (a) and near-city background (b). The horizontal lines indicate yearly mean frequencies. For explanation of the error bars, see the text.

is known to be related to local properties such as concentrations of precursors and condensable species, of existing aerosol particles, and meteorological conditions which determine the radiation flux, degree of atmospheric stagnation, or transport (Kiendler-Scharr et al., 2009). The monthly mean frequencies exhibited a remarkable seasonal variation, with a minimum in winter and two local maxima. In the city centre, the largest frequency happened in April, and a smaller maximum appeared in September. In the near-city background, two similar maxima occurred in March and September. The shift in the spring maxima for the two locations could easily be caused by differences between the particular years, and a longer-term observation has been in progress to refine this feature. The seasonal variation of the monthly mean nucleation frequency fits well into the second group of measurement sites reported by Manninen et al. (2010). It is worth mentioning that the K-puszta measurement site - which is also located in the Carpathian Basin - shows the same seasonal pattern. This suggests that nucleation events in the basin can take place in a larger area with the same occurrence properties. There were 43 and 31 nucleation days with continuous and uninterrupted growth process (i.e. class $1 \mathrm{~A}$ ) for
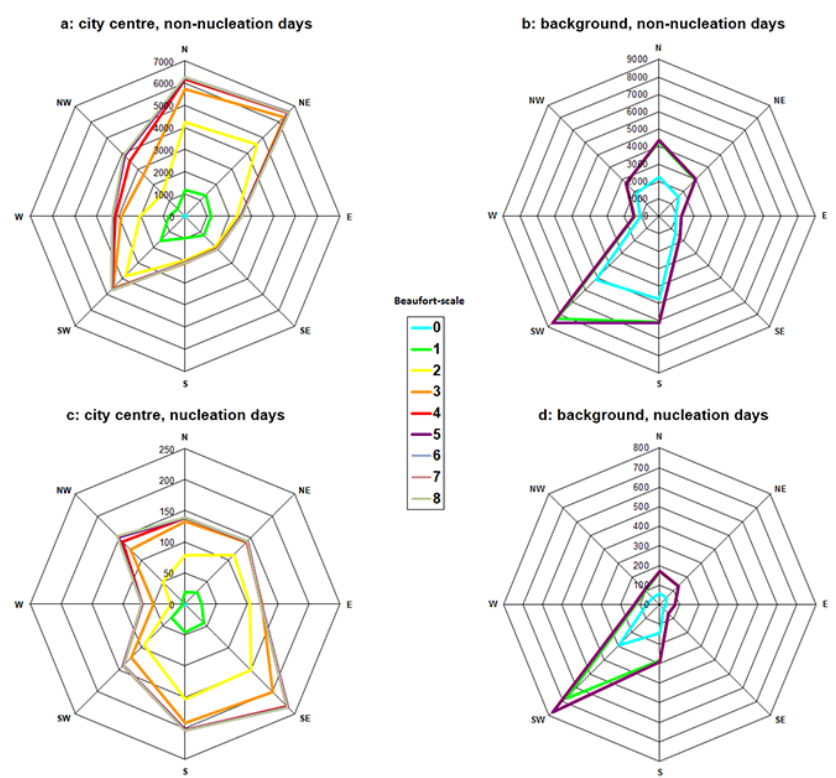

Figure 3. Wind roses for non-nucleation days (a) and for nucleation and growth intervals of class $1 \mathrm{~A}$ events (c) in the city centre, and for non-nucleation days (b) and for nucleation and growth intervals of class $1 \mathrm{~A}$ events (d) in the near-city background.

the near-city background and city centre, respectively. Detailed nucleation and growth properties are to be presented and discussed in a later article from other research aspects.

\subsection{Local wind speed and direction}

Overview statistics on the WS data at the city centre and near-city background for all days - and separately for nonnucleation days, nucleation, and growth interval of class $1 \mathrm{~A}$ events - are given in Table 1. The wind speed data in the city centre and near-city background were obtained at rather different altitudes of the meteorological sensors, and, therefore, the two sites are not comparable. In the city centre, there are no significant differences between the corresponding average (median and mean) wind speed values for the event intervals and non-nucleation days, while the average wind speed data for the urban background suggest that new particle formation and growth can be related to somewhat higher wind speeds. Prevailing local wind direction was $\mathrm{N}$ and $\mathrm{NE}$ (22 and $20 \%$, respectively, of all data) in the city centre, and SW and S (31 and 19\%, respectively) in the background. The difference can be explained by the actual location of the measurement sites (wind channel above the Danube at the city centre, and higher altitude of the background site). The wind roses for the non-nucleation days and event intervals in the city centre and near-city background are shown in Fig. 3. It is seen that the dominant local wind direction for the non-nucleation days in the city centre is NE-N. The average wind speeds for the different directions varied from 1.7 (SE) to $4.5 \mathrm{~m} \mathrm{~s}^{-1}$ (NW). The nucleation and growth intervals, 
Table 1. Ranges, medians, and means with standard deviations of the wind speed for all measurement days, and separately for nonnucleation days, for nucleation, and for growth intervals of class $1 \mathrm{~A}$ events at the city centre and near-city background.

\begin{tabular}{lrrr}
\hline Site/statistics & $\begin{array}{r}\text { All } \\
\text { days }\end{array}$ & $\begin{array}{r}\text { Non-nucleation } \\
\text { days }\end{array}$ & $\begin{array}{r}\text { Nucleation } \\
\text { intervals }\end{array}$ \\
\hline City centre & & & \\
\hline Minimum & 0.10 & 0.10 & 0.15 \\
Median & 2.6 & 2.4 & 2.7 \\
Maximum & 15.8 & 15.8 & 13.2 \\
Mean & 3.0 & 2.8 & 3.1 \\
Standard deviation & 2.0 & 1.85 & 1.73 \\
\hline Near-city background & & & \\
\hline Minimum & $<0.10$ & $<0.10$ & $<0.10$ \\
Median & $<0.10$ & $<0.10$ & 0.30 \\
Maximum & 3.1 & 2.7 & 3.1 \\
Mean & 0.24 & 0.25 & 0.46 \\
Standard deviation & 0.43 & 0.43 & 0.58 \\
\hline
\end{tabular}

however, are related to prevailing directions of SE and $\mathrm{S}$. The direction-dependent mean wind speed varied from 2.4 (E) to $4.3 \mathrm{~m} \mathrm{~s}^{-1}(\mathrm{NW})$. In the near-city background, the dominant local wind direction was SW-S for the non-nucleation days. The average wind speed for the different directions varied from $0.13(\mathrm{SE})$ to $0.32(\mathrm{~N}) \mathrm{m} \mathrm{s}^{-1}$. The nucleation and growth intervals were unambiguously associated with SW (44\% of all intervals) prevailing local wind directions. The directiondependent mean wind speed varied from 0.26 (E) to 0.53 (SW) $\mathrm{m} \mathrm{s}^{-1}$. This collectively implies that there seems to be a preferred wind direction during the nucleation and growth intervals from the southern geographical sectors.

\subsection{Arrival fields of nucleating air masses}

The arrival fields of the nucleating air masses derived by the method described in Sect. 2.2 for the city centre and nearcity background are shown in maps in Figs. 4 and 5, respectively. One event out of 43 cases in the near-city background was not evaluated because of some unfavourable particle growth properties. The areas are shown in yellow, and their overlapping sections (with multiplicity) are indicated in dark yellow $(1 \times)$, orange $(2 \times)$, and red $(3 \times)$. It is noted that the arrival fields depend sensitively on the actual meteorological parameters, mainly wind speed. The fields for the near-city background have a more complex character than for the city centre. It can be explained by the higher altitude of the background site (than for the city), for which the more open topographical character causes longer trajectories, longer trajectory segments, and larger areas in general. The map was divided into 4 field sectors (quarters) at the measurement sites considering the overall orientation of the trajectories, thus with horizontal and vertical axes. For the city

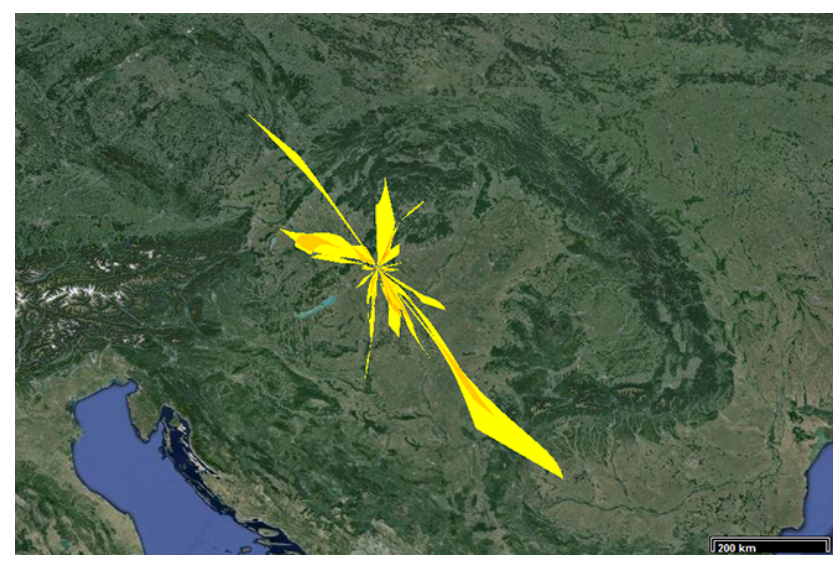

Figure 4. Arrival fields of nucleating air masses in the Carpathian Basin for the city centre of Budapest. The overlapping sections were indicated in stronger shaded colours (from yellow to orange).

centre, there were 8 and 13 arrival fields located in the NW and the SE quarters, while 5 fields were obtained in the NE and the SW quarters each. For the background, the NW quarter with 20 fields was absolutely dominating. There were 6 fields in the NE, and 8 fields in the SE and the SW quarters each. The arrival fields indicate that the nucleating air masses preferably arrived from the NW or the SE quarters. The direction of NW can be also biased with the regionally prevailing wind direction of NW, while the detailed explanation for the direction of SE needs further studies mainly on longer data sets. The results also suggest indirectly that the interactions between the city centre and near-city background may cause or influence local nucleation. Further experimental investigations at several sites in parallel are required to prove and quantify these interactions. Figures 4 and 5 also show that there were trajectories which originated outside of the Carpathian Basin. For the city centre and nearcity background, mean distance from the measurement site and its standard deviation for the longest relevant time parameter $\left(t_{1}\right)$ were $(121 \pm 102) \mathrm{km}$ and $(238 \pm 160) \mathrm{km}$, respectively. The difference between them can be again related to the higher altitude of the background site. For the city centre, mean height and its standard deviation of the starting points (for the time parameter $\left.t_{1}\right)$ were $(221 \pm 134) \mathrm{m}$, while the mean mixing layer depth and its standard deviation were $(1013 \pm 432) \mathrm{m}$. For the near-city background, the mean height and its standard deviation of the starting points were $(398 \pm 291) \mathrm{m}$, while the mean mixing layer depth and its standard deviation were $(460 \pm 255) \mathrm{m}$. These all mean that the nucleation events identified in Budapest occurred in the planetary boundary layer, but some (the longest) backward trajectories of nucleating air masses extended beyond the Carpathian Basin.

The relevant end point of a trajectory indicates the furthest distance where the new particle formation event likely extended. Indirect evidence suggests that, in most cases, 


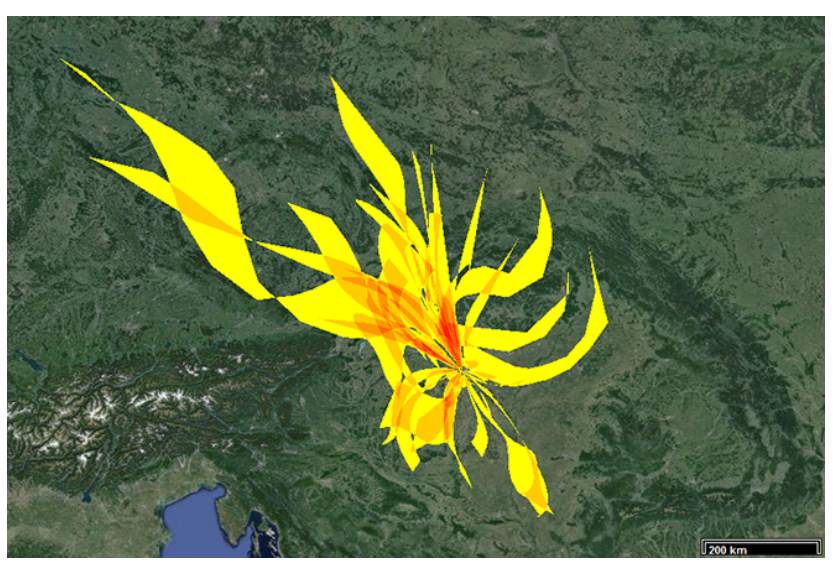

Figure 5. Arrival fields of nucleating air masses in the Carpathian Basin for the near-city background of Budapest. The overlapping sections were indicated in stronger shaded colours (from yellow through orange to red).

nucleation events happen more or less uniformly in $\mathrm{Bu}$ dapest, i.e. in the area comparable to the linear dimensions of the city (Salma et al., 2014). Therefore, the area of the city was projected by the backward trajectories that arrived at the slightly different spatial coordinates within Budapest at time $t_{\mathrm{e}}$ to the two limiting points of the segment on the longest trajectory (thus to the time intervals of $t_{\mathrm{e}}-t_{1}$ and $\left.t_{\mathrm{e}}-t_{2}\right)$. The furthest probable area of the nucleating air mass is expected to be inside them, and therefore the projected areas were joined into a polygon (nucleation field). The individual nucleation fields and their cross-sectional overlaps are shown on a map in Fig. 6. It is important to note that only those cases were included for which the end of the particle growth process could be clearly identified in the contour plot. The total number of these cases was 32. It is seen in Fig. 6 that the fields were situated in accordance with the trajectories; hence they were frequently located in the NW and NE field sectors. More importantly, many of them are within or close to larger forested territories. It is noted at the same time that some fields in rather limited numbers were observed in the eastern direction, and in Transylvania, which has considerable forests. The spatial distribution of the nucleation outlined in this paper can likely be improved or can be further specified as longer data sets and a larger number of events become available from continuous measurements.

\section{Conclusions}

The present study indicates that the air masses associated with regional-type new particle formation and growth events identified in Budapest spread horizontally across several hundreds of kilometres, and that this extension can often cover the bulk of the Carpathian Basin. This also implies that the nucleation events observable within the basin often occur

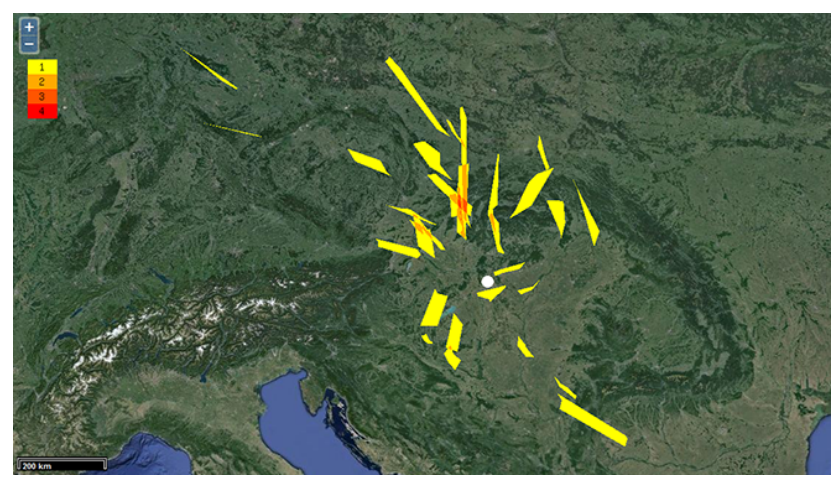

Figure 6. The furthest probable field of nucleating air masses in the Carpathian Basin observable in Budapest (marked by a white dot). The overlapping areas were indicated in stronger shaded colours (from yellow to red), and their multiplicity in overlapping is shown in the upper left corner.

in a coherent way. The role of the subtle differences in the boundary-layer dynamics, spatial concentration gradients, and local supersaturation quenching effects over some territories expectedly cause systematic or accidental local variability, and can result in the overall nucleation event not necessarily being realised simultaneously in the basin. Convection of large-scale nucleating air masses in the basin can not be excluded in some cases based on present knowledge. Rigorous analysis of long-term data sets from several different measurement stations is required to decide on these indirect indications.

Acknowledgements. Financial support by the Hungarian Scientific Research Fund (contract K84091) is appreciated. The authors thank M. Gede of the Eötvös University, Department of Cartography and Geoinformatics, for his assistance in generating the maps, and P. Ábrahám, director, Gy. Mezô and A. Holl, researchers, of the Konkoly Observatory of the Hungarian Academy of Sciences for their support during the field measurement there. Figures 4-6 were generated using Google Maps Engine.

Edited by: V.-M. Kerminen

\section{References}

Andreae, M. O. and Rosenfeld, D.: Aerosol-cloud-precipitation interactions. Part 1. The nature and sources of cloud-active aerosols, Earth-Sci. Rev., 89, 13-41, 2008.

Borsós, T., Řimnáčová, D., Ždímal, V., Smolík, J., Wagner, Z., Weidinger, T., Burkart, J., Steiner, G., Reischl, G., Hitzenberger, R., Schwarz, J., and Salma, I.: Comparison of particulate number concentrations in three Central European capital cities, Sci. Total Environ., 433, 418-426, 2012. 
Clarke, A., Davis, D., Kapustin, V., Eisele, F., Chen, G., Paluch, I., Lenschow, D., Bandy, A., Thornton, D., Moore, K., Mauldin, L., Tanner, D., Litchy, M., Carroll, M., Collins, J., and Albercook, G.: Particle nucleation in the tropical boundary layer and its coupling to marine sulfur sources, Science, 282, 89-92, 1998.

Clarke, A., Eisele, F., Kapustin, V., Moore, K., Tanner, D., Mauldin, L., Litchy, M., Lienert, B., Carroll, M., and Albercook, G.: Nucleation in the equatorial free troposphere: Favorable environments during PEM-Tropics, J. Geophys. Res., 104, 5735-5744, 1999.

Coe, H., Williams, P. I., McFiggans, G., Gallagher, M. W., Beswick, K. M., Bower, K. N., and Choularton, T. W.: Behavior of ultrafine particles in continental and marine air masses at a rural site in the United Kingdom, J. Geophys. Res., 105, 26891-26905, 2000.

Dal Maso, M., Kulmala, M., Riipinen, I., Wagner, R., Hussein, T., Aalto, P. P., and Lehtinen, K. E. J.: Formation and growth of fresh atmospheric aerosols: eight years of aerosol size distribution data from SMEAR II, Hyytiälä, Finland, Boreal Environ. Res., 10, 323-336, 2005.

Dall'Osto, M., Querol, X., Alastuey, A., O’Dowd, C., Harrison, R. M., Wenger, J., and Gómez-Moreno, F. J.: On the spatial distribution and evolution of ultrafine particles in Barcelona, Atmos. Chem. Phys., 13, 741-759, doi:10.5194/acp-13-741-2013, 2013.

Draxler, R. R. and Rolph, G. D.: HYSPLIT (HYbrid Single-Particle Lagrangian Integrated Trajectory) Model, NOAA Air Resources Laboratory, College Park, MD, 2013, http://www.arl.noaa.gov/ HYSPLIT.php (last access: 20 February 2014), 2013.

Fiedler, V., Dal Maso, M., Boy, M., Aufmhoff, H., Hoffmann, J., Schuck, T., Birmili, W., Hanke, M., Uecker, J., Arnold, F., and Kulmala, M.: The contribution of sulphuric acid to atmospheric particle formation and growth: a comparison between boundary layers in Northern and Central Europe, Atmos. Chem. Phys., 5, 1773-1785, doi:10.5194/acp-5-1773-2005, 2005.

HEI Review Panel on Ultrafine Particles: Understanding the Health Effects of Ambient Ultrafine Particles. HEI Perspectives 3. Health Effects Institute, Boston, 2013.

Hirsikko, A., Vakkari, V., Tiitta, P., Hatakka, J., Kerminen, V.-M., Sundström, A.-M., Beukes, J. P., Manninen, H. E., Kulmala, M., and Laakso, L.: Multiple daytime nucleation events in semi-clean savannah and industrial environments in South Africa: analysis based on observations, Atmos. Chem. Phys., 13, 5523-5532, doi:10.5194/acp-13-5523-2013, 2013.

Hussein, T., Junninen, H., Tunved, P., Kristensson, A., Dal Maso, M., Riipinen, I., Aalto, P. P., Hansson, H.-C., Swietlicki, E., and Kulmala, M.: Time span and spatial scale of regional new particle formation events over Finland and Southern Sweden, Atmos. Chem. Phys., 9, 4699-4716, doi:10.5194/acp-9-4699-2009, 2009.

Kerminen, V.-M., Paramonov, M., Anttila, T., Riipinen, I., Fountoukis, C., Korhonen, H., Asmi, E., Laakso, L., Lihavainen, H., Swietlicki, E., Svenningsson, B., Asmi, A., Pandis, S. N., Kulmala, M., and Petäjä, T.: Cloud condensation nuclei production associated with atmospheric nucleation: a synthesis based on existing literature and new results, Atmos. Chem. Phys., 12, $12037-$ 12059, doi:10.5194/acp-12-12037-2012, 2012.
Kiendler-Scharr, A., Wildt, J., Dal Maso, M., Hohaus, T., Kleist, E., Mentel, T. F., Tillmann, R., Uerlings, R., Schurr, U., and Wahner, A.: New particle formation in forests inhibited by isoprene emissions, Nature, 461, 381-384, 2009.

Komppula, M., Sihto, S.-L., Korhonen, H., Lihavainen, H., Kerminen, V.-M., Kulmala, M., and Viisanen, Y.: New particle formation in air mass transported between two measurement sites in Northern Finland, Atmos. Chem. Phys., 6, 2811-2824, doi:10.5194/acp-6-2811-2006, 2006.

Kreyling, W. G., Semmler-Behnke, M., and Möller, W.: Ultrafine particle-lung interactions: does size matter?, J. Aerosol Med., 19, 74-83, 2006.

Kristensson, A., Dal Maso, M., Swietlicki, E., Hussein, T., Zhou, J., Kerminen, V.-M., and Kulmala, M.: Characterization of new particle formation events at a background site in Southern Sweden: relation to air mass history, Tellus, 60B, 330-344, 2008.

Kristensson, A., Johansson, M., Swietlicki, E., Kivekäs, N., Hussein, T., Nieminen, T., Kulmala, M., and Dal Maso, M. NanoMap: Geographical mapping of atmospheric new particle formation through analysis of particle number size distribution and trajectory data, Boreal Env. Res., 19, 329- 342, 2014.

Kulmala, M., and Kerminen, V.-M.: On the formation and growth of atmospheric nanoparticles, Atmos. Res., 90, 132-150, 2008.

Kulmala, M., Toivonen, A., Mäkelä, J., and Laaksonen, A.: Analysis of the growth of nucleation mode particles observed in boreal forest, Tellus, 50B, 449-462, 1998.

Kulmala, M., Dal Maso, M., Mäkelä, J., Pirjola, L., Väkevä, M., Aalto, P., Miikkulainen, P., Hämeri, K., and O'Dowd, C.: On the formation, growth and composition of nucleation mode particles, Tellus, 53B, 479-490, 2001.

Kulmala, M., Vehkamäki, H., Petäjä, T., Dal Maso, M., Lauri, A., Kerminen, V., Birmili, W., and McMurry, P.: Formation and growth rates of ultrafine atmospheric particles: a review of observations, J. Aerosol Sci., 35, 143-176, 2004.

Kulmala, M., Kontkanen, J., Junninen, H., Lehtipalo, K., Manninen, H. E. Nieminen, T., Petäjä, T., Sipilä, M., Schobesberger, S., Rantala, P., Franchin, A., Jokinen, T., Järvinen, E., Äijälä, M., Kangasluoma, J., Hakala, J., Aalto, P. P., Paasonen, P., Mikkilä, J., Vanhanen, J., Aalto, J., Hakola, H., Makkonen, U., Ruuskanen, T., Mauldin III, R. L., Duplissy, J., Vehkamäki, H., Bäck, J., Kortelainen, A., Riipinen, I., Kurtén, T., Johnston, M. V., Smith, J. N., Ehn, M., Mentel, T. F., Lehtinen, K. E. J., Laaksonen, A., Kerminen, V.-M., and Worsnop, D. R.: Direct observations of atmospheric aerosol nucleation, Science, 339, 943-946, 2013.

Laaksonen, A., Korhonen, P., Kulmala, M., and Charlson, R. J.: Modification of the Köhler equation to include soluble trace gases and slightly soluble substances, J. Atmos. Sci., 55, 853862, 1998.

Makkonen, R., Asmi, A., Kerminen, V.-M., Boy, M., Arneth, A., Hari, P., and Kulmala, M.: Air pollution control and decreasing new particle formation lead to strong climate warming, Atmos. Chem. Phys., 12, 1515-1524, doi:10.5194/acp-12-15152012, 2012. 
Manninen, H. E., Nieminen, T., Asmi, E., Gagné, S., Häkkinen, S., Lehtipalo, K., Aalto, P., Vana, M., Mirme, A., Mirme, S., Hõrrak, U., Plass-Dülmer, C., Stange, G., Kiss, G., Hoffer, A., Töro, N., Moerman, M., Henzing, B., de Leeuw, G., Brinkenberg, M., Kouvarakis, G. N., Bougiatioti, A., Mihalopoulos, N., O'Dowd, C., Ceburnis, D., Arneth, A., Svenningsson, B., Swietlicki, E., Tarozzi, L., Decesari, S., Facchini, M. C., Birmili, W., Sonntag, A., Wiedensohler, A., Boulon, J., Sellegri, K., Laj, P., Gysel, M., Bukowiecki, N., Weingartner, E., Wehrle, G., Laaksonen, A., Hamed, A., Joutsensaari, J., Petäjä, T., Kerminen, V.-M., and Kulmala, M.: EUCAARI ion spectrometer measurements at 12 European sites - analysis of new particle formation events, Atmos. Chem. Phys., 10, 7907-7927, doi:10.5194/acp-10-79072010, 2010.

Merikanto, J., Spracklen, D. V., Mann, G. W., Pickering, S. J., and Carslaw, K. S.: Impact of nucleation on global CCN, Atmos. Chem. Phys., 9, 8601-8616, doi:10.5194/acp-9-8601-2009, 2009.

Minikin, A., Petzold, A., Ström, J., Krejčí, R., Seifert, M., van Velthoven, P., Schlager, H., and Schumann, U.: Aircraft observations of the upper tropospheric fine particle aerosol in the Northern and Southern Hemispheres at midlatitudes, Geophys. Res. Lett., 30, 1503, doi:10.1029/2002GL016458, 2003.

Oberdörster, G., Oberdörster, E., and Oberdörster, J.: Nanotoxicology: an emerging discipline evolving from studies of ultrafine particles. Environ. Health Perspect, 113, 823-839, 2005.

Qian, S., Sakurai, H., and McMurry, P. H.: Characteristics of regional nucleation events in urban East St. Louis, Atmos. Environ., 41, 4119-4127, 2007.

Salma, I., Borsós, T., Weidinger, T., Aalto, P., Hussein, T., Dal Maso, M., and Kulmala, M.: Production, growth and properties of ultrafine atmospheric aerosol particles in an urban environment, Atmos. Chem. Phys., 11, 1339-1353, doi:10.5194/acp-111339-2011, 2011.

Salma, I., Borsós, T., Németh, Z., Weidinger, T., Aalto, P., and Kulmala, M.: Comparative study of ultrafine atmospheric aerosol within a city, Atmos. Environ., 92 154-161, 2014.

Spracklen, D. V., Carslaw, K. S., Merikanto, J., Mann, G. W., Reddington, C. L., Pickering, S., Ogren, J. A., Andrews, E., Baltensperger, U., Weingartner, E., Boy, M., Kulmala, M., Laakso, L., Lihavainen, H., Kivekäs, N., Komppula, M., Mihalopoulos, N., Kouvarakis, G., Jennings, S. G., O’Dowd, C., Birmili, W., Wiedensohler, A., Weller, R., Gras, J., Laj, P., Sellegri, K., Bonn, B., Krejci, R., Laaksonen, A., Hamed, A., Minikin, A., Harrison, R. M., Talbot, R., and Sun, J.: Explaining global surface aerosol number concentrations in terms of primary emissions and particle formation, Atmos. Chem. Phys., 10, 4775-4793, doi:10.5194/acp-10-4775-2010, 2010.

Vana, M., Kulmala, M., Dal Maso, D., Hörrak, M., and Tamm, E.: Comparative study of nucleation mode aerosol particles and intermediate air ions formation events at three sites, J. Geophys. Res., 109, D17201, doi:10.1029/2003JD004413, 2004.
Väänänen, R., Kyröö, E.-M., Nieminen, T., Kivekäs, N., Junninen, H., Virkkula, A., Dal Maso, M., Lihavainen, H., Viisanen, Y., Svenningsson, B., Holst, T., Arneth, A., Aalto, P. P., Kulmala, M., and Kerminen, V.-M.: Analysis of particle size distribution changes between three measurement sites in northern Scandinavia, Atmos. Chem. Phys., 13, 11887-11903, doi:10.5194/acp13-11887-2013, 2013.

Wang, M. and Penner, J. E.: Aerosol indirect forcing in a global model with particle nucleation, Atmos. Chem. Phys., 9, 239-260, doi:10.5194/acp-9-239-2009, 2009.

Wiedensohler, A., Cheng, Y. F., Nowak, A., Wehner, B., Achtert, P., Berghof, M., Birmili, W., Wu, Z. J., Hu, M., Zhu, T., Takegawa, N., Kita, K., Kondo, Y., Lou, S. R., Hofzumahaus, A., Holland, F., Wahner, A., Gunthe, S. S., Rose, D., Su, H., and Pöschl, U.: Rapid aerosol particle growth and increase of cloud condensation nucleus activity by secondary aerosol formation and condensation: A case study for regional air pollution in northeastern China, J. Geophys. Res., 114, D00G08, doi:10.1029/2008JD010884, 2009.

Wiedensohler, A., Birmili, W., Nowak, A., Sonntag, A., Weinhold, K., Merkel, M., Wehner, B., Tuch, T., Pfeifer, S., Fiebig, M., Fjäraa, A. M., Asmi, E., Sellegri, K., Depuy, R., Venzac, H., Villani, P., Laj, P., Aalto, P., Ogren, J. A., Swietlicki, E., Williams, P., Roldin, P., Quincey, P., Hüglin, C., Fierz-Schmidhauser, R., Gysel, M., Weingartner, E., Riccobono, F., Santos, S., Grüning, C., Faloon, K., Beddows, D., Harrison, R., Monahan, C., Jennings, S. G., O’Dowd, C. D., Marinoni, A., Horn, H.-G., Keck, L., Jiang, J., Scheckman, J., McMurry, P. H., Deng, Z., Zhao, C. S., Moerman, M., Henzing, B., de Leeuw, G., Löschau, G., and Bastian, S.: Mobility particle size spectrometers: harmonization of technical standards and data structure to facilitate high quality long-term observations of atmospheric particle number size distributions, Atmos. Meas. Tech., 5, 657-685, doi:10.5194/amt5-657-2012, 2012.

Young, L. H., Benson, D. R., Montanaro, W. M., Lee, S. H., Pan, L. L., Rogers, D. C., Jensen, J., Stith, J. L., Davis, C. A., Campos, T. L., Bowman, K. P., Cooper, W. A., and Lait, L. R.: Enhanced new particle formation observed in the northern midlatitude tropopause region, J. Geophys. Res., 112, D10218, doi:10.1029/2006jd008109, 2007.

Yu, F., Luo, G., Bates, T. S., Anderson, B., Clarke, A., Kapustin, V., Yantosca, R. M., Wang, Y., and Wu, S.: Spatial distributions of particle number concentrations in the global troposphere: Simulations, observations, and implications for nucleation mechanisms, J. Geophys. Res., 115, D17205, doi:10.1029/2009JD013473, 2010. 